\title{
France in 1940 in British Eyes
}

La France en 1940 aux yeux des Britanniques

\section{Richard Carswell}

\section{(2) OpenEdition \\ 1 Journals}

Electronic version

URL: https://journals.openedition.org/rfcb/8690

ISSN: 2429-4373

Publisher

CRECIB - Centre de recherche et d'études en civilisation britannique

\section{Electronic reference}

Richard Carswell, "France in 1940 in British Eyes", Revue Française de Civilisation Britannique [Online] XXVII-1 | 2022, Online since 04 January 2022, connection on 01 February 2022. URL: http:// journals.openedition.org/rfcb/8690

This text was automatically generated on 1 February 2022

\section{(c) (†) $\ominus$}

Revue française de civilisation britannique est mis à disposition selon les termes de la licence Creative Commons Attribution - Pas d'Utilisation Commerciale - Pas de Modification 4.0 International. 


\title{
France in 1940 in British Eyes
}

\author{
La France en 1940 aux yeux des Britanniques
}

\author{
Richard Carswell
}

\section{Introduction}

1 What did the British think of the fall of France in 1940? By the fall of France I mean what most historians call the military defeat of May-June and the end of the Third Republic in July. To find an answer to the question, a good starting place is the book, published over forty years ago by the late Philip Bell, entitled A Certain Eventuality: Britain and the Fall of France. ${ }^{1}$ It is an account of how Britain's political and military leaders reacted to the crisis. The book draws heavily on the government documents which are housed in The National Archives at Kew in south west London. As numerous diaries and memoirs also indicate, Bell shows how Britain's leaders - like many people around the world - were astounded and dismayed by the speed and relentlessness of Germany's crushing military victory.

Bell wrote a short chapter in his book on British public opinion and the fall of France, in which he quoted extensively from the national press. Although the British press is a useful guide to what some people - the more educated and informed - were thinking at the time, there remains the perennial question whether the press reflected or moulded public opinion. Moreover, the press was not entirely free. It was subject to guidance by the authorities. For example, during the battle of France the government directed that there should be no public recriminations between the Allies; and the press largely followed that direction. Nevertheless, newspapers and periodicals do give us some insight into wider British thinking at the time.

3 As far as more popular opinion is concerned, a useful source is contained in the socalled Home Intelligence Reports compiled by the Ministry of Information in 1940. These Reports were a form of qualitative opinion polling, conducted almost daily if somewhat unscientifically during the summer of 1940 . They were an attempt to monitor and measure public morale at a time of acute crisis. The Reports are available for consultation at The National Archives under the rubric of the Ministry of 
Information. They have also been collected in a volume edited by Paul Addison and Jeremy Crang called Listening to Britain: Home Intelligence Reports on Britain's Finest Hour May to September 1940, published in 2010. ${ }^{2}$

\section{Popular opinion}

4 What do the Home Intelligence Reports tell us? As one would expect, popular opinion was volatile in the period from May to July 1940. The German invasion began on 10 May 1940. At first, people were scarcely affected or were bewildered by events in France. Information about the opening stages of the battle was sparse. This initial lack of information was filled by wild, fantastic and implausible rumours, some similar to those circulating in France at the time. One rumour claimed that the Commander in Chief of the Allied forces, General Maurice Gamelin, had committed suicide. In fact, he had been relieved of his command by the French Prime Minister Paul Reynaud on 19 May. Soon rumours were replaced by reported facts. It was clear that the German advance into France was not being stopped. Two weeks after the beginning of the invasion, German forces had crossed the Ardennes Forest and the River Meuse and had reached the Channel coast near Abbeville, cutting off the Allied armies in the north from the main bulk of French forces in the south. By now the Germans were also attacking Calais and Boulogne. The popular mood in Britain began to change, according to the Home Intelligence Reports. The summary of the Report for 24 May revealed that:

A new feature today is a great increase and sometimes intense violence of criticism against the French. 'The French are letting us down.' [It is said] ...The French are now becoming the scapegoat ... there is a prevalent feeling that if we are defeated, the French will have been to blame. There was plenty of evidence during the last few months that there was no nationwide feeling of affection and brotherliness for our ally. Confidence in [the] French social structure as well as in the power of French arms has been badly shaken. The consequences of this may be dangerous. ${ }^{3}$

5 The Government felt compelled to counter such pessimism. The newly appointed Minister of Information, Alfred Duff Cooper, told radio listeners of the BBC on 28 May:

If anybody says to you: 'The French have let us down', you ought to reply: 'Either you are a paid agent of Germany, or else you are an unpaid one doing German propaganda for nothing. In either case your mouth should be shut and silenced because you are an enemy, and a most dangerous enemy to the Allied cause. ${ }^{4}$

6 The Allies' military position continued to deteriorate. The Dutch had capitulated. The Belgian King announced he was seeking a stop to the fighting. Two days later the Daily Express argued that Britain had to admit its mistakes as frankly as Reynaud had admitted France's mistakes: "the people of Britain lingered long in slothfulness while France was fully mobilised for war. All this belongs to the past ... Henceforth we are not two nations, but one united force. ${ }^{\prime 5}$ On 31 May The Manchester Guardian considered it:

strange to read long exhortations to the people of this country not to reproach the French for errors committed at the beginning of this war. But who reproaches them; and what time is this for reproaches among those who are bound together, to live or die, in a most sacred cause? Let us assume that the French have learned their lesson and let us see to it that we ourselves, while there is yet time, learn the bitter lessons that the war, daily, is teaching us. ${ }^{6}$

What was left unsaid by the press was whether or not it was too late to learn these 'bitter lessons' of the war. 
On 3 June Paris was bombed; civilians were killed. ${ }^{7}$ For Geoffrey Cox of the Daily Express, "it was as if someone had slashed the face of a beautiful woman." ${ }^{8}$ The air raid would "arouse the deepest sympathy for the French people", wrote the Daily Mail, "It renews our own resolve to crush the authors of this outrage." Broadcasting from Paris that evening, Duff Cooper told his British radio listeners that:

the French know very well that they are fighting for their life. ... They are a very tough people, the French people; very different from us, and often difficult for us to understand, but they have two things that matter: love of their own country, and courage to die for it. So long as our two peoples remain commonly united, there is no cause for fear. Two such peoples could not be defeated, even if they stood alone together - but they do not stand alone. ${ }^{10}$

According to Home Intelligence, the bombing of Paris had become "the dominant topic of conversation today." It had "affected [British] people in a special way. Paris, for this purpose, is London and the reality of air raids on London has been brought home." 11 Thus "anti-French feeling has strongly declined today ... The French are suffering what we shall soon suffer. The French are, therefore, more nearly ourselves than at any previous time." 12 But Home Intelligence thought it "a matter of anxiety" that popular feeling could swing extremely easily. On 5 June, by which time over 330,000 British, French and Allied troops had been evacuated by sea from Dunkirk, Home Intelligence reported that Churchill's reference to Britain fighting alone (if need be) had caused "apprehension throughout the country" and "some slight increase in doubt about the intentions of our ally. Consequently our close study of anti-French feeling shows that it has increased." 13

By Monday 10 June, the day on which Italy declared war on the Allies and the French government quit Paris for Touraine, Home Intelligence reported that the course of events in France was "dispelling the superficial expression of anti-French feeling. That feeling, however, is still latent and may have to be reckoned with in the future." ${ }^{14}$ The fall of Paris on 14 June "brought some slight relaxation of tension", according to Home Intelligence. "The heart is heavy and sadness broods over conversation. There is relief that Paris has been spared by withdrawal, and opinions about the strategic value of the capital are confused. There is disquiet but no feeling of panic." ${ }^{15}$

11 Marshal Pétain's request for an armistice on 17 June caused "confusion and shock, but hardly surprise", Home Intelligence wrote. "From all parts come reports of bewilderment and great anxiety" about the fate of the British Expeditionary Force and about the French Army and Navy. "Are they going to fight on with us? If not, things are indeed black." ${ }^{16}$ The next day Home Intelligence remarked that there was "extremely little anti-French feeling and the PM's [Prime Minister's broadcast] remarks about 'the [gallant] French people' are fully in line with public opinion." ${ }^{17}$ But, in his speech on 18 June in the House of Commons on Britain's "finest hour", Churchill argued that Britain had done all that it could to assist France in the battle and that it was not the time to indulge in recriminations against his and previous British governments for their alleged failures. ${ }^{18}$ Churchill's references to France "brought a recrudescence of anti-French feeling. The latency of anti-French feeling must never be forgotten", Home Intelligence insisted.

There has never been much sympathy with the French point of view but there are some indications that the present wave of anti-French feeling is bringing to the surface antagonism against 'French politicians', 'Corruption in high quarters', 'Traitors'. This feeling finds some parallel in active criticisms of our own leadership. 19

12 The Report of the following day suggested that: 
There continues to be a slight improvement in the atmosphere of depression that followed the French capitulation [sic]. There is a decline in interest in Hitler's expected peace terms, but this is coupled with a definite increase in anti-French feeling, showing itself in such phrases as 'We're better off without the French', 'We should have looked after ourselves all along'. If the French capitulation ultimately includes the French Navy and Air Force some Regions [of Britain] anticipate a growth of very bitter feeling. ${ }^{20}$

13 In the meantime, partly at the authorities' prompting, all the mainstream press reported General de Gaulle's broadcast of 18 June on the BBC that the war was not lost and that the fight must go on. The broadcast stimulated uplifting editorials, including one in the Daily Sketch entitled 'The Spirit of France Lives'. ${ }^{21}$ At the level of the man in the street, it naturally took time for the significance of de Gaulle's position to be appreciated. On 21 June Home Intelligence reported from the Kodak camera factory in Harrow in north London that "Anti-French feeling [is] growing very strong since [the] capitulation. People remember at [the] end of [the] last war our soldiers said they would rather fight with the Germans than with the French". ${ }^{22}$ And three days later, on 24 June, while in the north western region "De Gaulle's broadcast made a good impression", Home Intelligence reported that:

at all levels of society the opinion is bitterly and vigorously expressed that the French people have been betrayed by the 'politicians'. Indignation against French leaders ... increased after the announcement of the terms [of the armistice]. There are no signs that this indignation is directed against the French people with whom there is considerable sympathy. ${ }^{23}$

14 On the same day, the press quoted de Gaulle's condemnation of the armistice. It was "not only a capitulation but a submission to slavery." So long as France's allies continued the war, "her Government had not the right to surrender to the enemy ... This war is a world war ... Honour, common sense, the interest of the country demand that all free Frenchmen should continue the fight." ${ }^{24}$ At the same time, on 25 June, the day on which the German and Italian armistices came into effect, according to the Home Intelligence Report, in southern England "all classes show increased bitterness against France, due largely to [the] failure to distinguish between [the] Government and [the] public." ${ }^{25}$ The press did not share that failing. It was very severe in condemning Pétain and his government. The Daily Sketch would not "waste time disputing with a man who was once a French soldier the meaning of the word 'honour."' ${ }^{6}$ De Gaulle told Pétain: "you played a losing game, threw down your cards, emptied our pockets, as if we had no trumps left." Now "M. le Maréchal" had called on France to rise again. "But in what sort of atmosphere, by what sort of means, in what name do you expect her to rise again beneath the German jackboot and the Italian dancing-slipper?" 27 After the British attack on the French fleet at Mers-el-Kébir at the beginning of July, Home Intelligence reported "some growth of anti-French feeling of an indiscriminate kind. Most people condemn the Pétain government, but some say 'we shall be fighting the French soon,' [others say] 'we were never real friends with the French"'. ${ }^{28}$

In summary, the government and the press by and large refrained from public recriminations against the French for the military defeat. Yet it appears that popular opinion turned against France, because - according to Home Intelligence - it failed to distinguish between the actions of the French government and the French people. While the press made a clear distinction between the French government and the French people, the Home Intelligence Reports reveal a pattern of ambiguous and sometimes contradictory popular attitudes: a mixture of compassion for the plight of the French people, contempt for the country's leaders for agreeing to the armistice, 
and burgeoning resentment that France had stopped fighting and abandoned its ally to face the enemy alone. Perhaps, given the dramatic and bewildering nature of the dizzyingly fast-paced events of the previous two months, it was not surprising that ordinary people experienced such a jumble of emotions. But was the pattern now fixed? According to a memorandum from the Ministry of Information to the Cabinet in late July 1940, "few English people would be found willing to make sacrifices" on France's behalf. ${ }^{29}$

\section{Questions for further research}

How representative of public opinion as a whole - or at least of a majority of public opinion - were the views portrayed in the press and in the Home Intelligence Reports? It is difficult to know for sure. The question surely merits further research. In their introduction Addison and Crang judge the quality of the evidence in the Home Intelligence Reports as "uneven" and "invariably impressionistic"; but the Reports were " $a$ genuine attempt to synthesise the best available sources." ${ }^{30}$ Certainly, opinions in Britain varied. As Philip Bell wrote in another book, there was "a small but ardent company of British Francophiles, who in June 1940 suffered a sense of loss so acute as to amount almost to bereavement." ${ }^{11}$ Some contemporary diaries provide evidence of sympathy for France and even an understanding of how the French could blame the British for having abandoned them at Dunkirk. ${ }^{32}$ We know also that individual French men and women present in Britain in the summer of 1940 were shown great kindness and generosity by some of the ordinary local population, even if "government officials could often be uncaring and critical." ${ }^{33}$ Moreover, there was no Francophobia in that famous polemic published in July 1940, Guilty Men by 'Cato', castigating Britain's leaders for the plight which the country found itself in. Rather, the book wrote of the "unsurpassable heroism" of the French. ${ }^{34}$ On the other hand, broadcasting on Bastille Day in 1940, no less a personage than the Prime Minister, Winston Churchill, conveyed a mixed message. He was sure that France would rise again and he argued against reproaches.

When you have a friend and comrade at whose side you have faced tremendous struggles, and your friend is smitten down by a tremendous blow, it may be necessary to make sure that the weapon that has fallen from his hand shall not be added to the resources of your common enemy. But you need not bear malice because of your friend's cries of delirium and gestures of agony.

But, in praising the morale of the British people. Churchill also claimed that many of the countries invaded by Hitler had

been poisoned by intrigue before they were struck down by violence. They have been rotted from within before they were smitten from without. How else can you explain what has happened to France, to the French Army, to the French people, to the leaders of the French people? ${ }^{35}$

Churchill's apparently wholesale condemnation of France was bound to have its effects, direct or indirect. Thus, later that year, in the novel Return Via Dunkirk by 'Gun Buster' (a pseudonym), the story of the movements of an artillery regiment of the British Expeditionary Force during the Phoney War and the Battle of Flanders has tinges of Francophobia. Of the regiment's encounter with an unnamed French mechanised column on the same road during the battle, the narrator remarks: "As usual, no march discipline, very disorderly, and living up to the French Army's motto on the move: 'Get there anyhow, as soon as possible, and don't bother about pushing other people off the road." Later the narrator found the town of Méricourt 
crowded with French infantry on the retreat, very tired and dirty, very disorderly, displaying days of beard, bits of wet cigarettes hanging from their lips. I remember thinking how philosophical [sic] they appeared to take things; and then, that it wasn't philosophy at all, but rather an ominous sort of indifference. Produced in 1942 by Michael Balcon and directed by Alberto Cavalcanti, the film is a fiction about a sleepy, picturesque English village infiltrated by German soldiers disguised in British military uniforms assisted by the local fifth column. Based on a short story by Graham Greene, the film features the scene of a dinner party in which la notable du village, the lady of the local manor house, Mrs Fraser, is "furious" at the thought of "the Germans gorging themselves on French wines." She is interrupted by Nora, the spinster daughter of the local vicar. Nora hasn't "much sympathy for the French [she says] ... They let us down so abominably. I think they deserve to suffer for it." Mrs Fraser disagrees vigorously. ${ }^{37}$ The dialogue demonstrates the ambiguity of popular attitudes towards France's appalling misfortune. There is no disguising the resentment. It points also to the notion that there was a reckoning of accounts to be made in the future between the former allies. In the same year as the making of Went The Day Well?, Sybil Eccles, the wife of a British diplomat, wrote to her husband as follows:

At the time of Dunkirk we told ourselves too often that we bore the French no grudge - patting ourselves on the back for a magnanimity that was not genuinely felt. Beneath the skin and in the guts, age-old resentments seethed and bubbled anew - and the wound has festered ever since. It will take a good deal of skill and education to put things right. ${ }^{38}$

Or, as Richard Weight interprets her letter, she was warning her husband "that the quick collapse of the Third Republic had aggravated the perennial Francophobia of the British." ${ }_{39}$

of course, we cannot forget the other side of the coin, namely the anger felt by the French that it was they - not Britain - who had been abandoned - by the Dutch, the Belgians and, above all, by the British. Indeed, the theme of perfidious Albion was replayed fortissimo by the Vichy regime and the pro-German collaborationists in Paris during the war, and - although più piano - even by more detached French observers such as the anglophile banker and economist Charles Rist writing in November 1940:

Certainly, one could reproach England for many things, most especially her way of using France as a bastion against Germany. In the preceding war, she waited until 1917 to take over an important sector of the front. During that period France lost a million men. When Baldwin proclaimed that the English frontier was on the Rhine (that was in 1935), the English did nothing to prepare themselves. That is because they were still counting on France to hold out until England was ready. The draft came only much later; three months ago, English men over twenty-seven years of age had still not been mobilized! ... And what can one say regarding their perpetual collusion with the Germans after the peace of 1918 ? ... Perhaps now they are under attack, the English will understand that they are the ones directly targeted by German hegemony. Vanity prevented their understanding that in $1918 .{ }^{40}$ 
Who abandoned whom? Historians agree that, in 1940, Britain and France chose separate paths. The Franco-British alliance imploded. Relations between Britain and the Vichy regime were strained and on occasion dangerously close to open warfare. True, Britain supported de Gaulle and the Free French throughout the war through ups and downs. True, the formal alliance between the two countries was revived in 1947 in the Treaty of Dunkirk, even if Germany was no longer the dangerous enemy that it had been. Yet, as far as the pre-war past was concerned, there was an urge among some to apportion blame for the disaster of 1940. It was noteworthy when a commentator took a dispassionate view. One such was Harold Butler, a former British official of the League of Nations, who wrote in 1941 of the lost peace:

In the face of the present calamity it is not for us to throw any stones. We too were duped, short-sighted, vacillating, and intensely pacific, until war was actually upon us. We too were only half-armed, but we had the good fortune to live on an island. But the future of France is of immense importance to us, not so much as a military counterweight to Germany, but as the home of the democratic ideal on the Continent. We have not merely to defeat Germany but the German spirit, which has found its supreme expression in the Nazi creed. To do this we have not only to liberate France but also to liberate the French spirit. That it still exists under the German heel we need not doubt. The Vichy period is a purgatory through which France is condemned to pass, but once the nation is free from its fetters its old faith in liberty will flare up with a purer fire. ... Somehow or other a new France will emerge, perhaps before the struggle is over, again to become the partner of the British and American peoples in rebuilding a free and peaceful world, in which the individual is not at the mercy of the state, but the state at the service of the individual. That after all is the essence of the French spirit and the real bond between them and ourselves. However different our habits and temperaments and outlooks - and they will always be profoundly different - we cannot forget what we have owed to France in the past or what we expect of her in the future. ${ }^{41}$

And in 1944 British forces landing in France were told by their superiors not to reignite any Franco-British animosity.

Don't criticize the French Army's defeat of 1940. ... Don't get into arguments about religion or politics. If a Frenchman raises one of the points which have strained Anglo-French relations since 1940, drop the matter. There are two sides to every question, but you don't want to take either..$^{42}$

But it was too tempting to ignore such judicious advice. In Britain the myths that germinated in the year of 1940 joined forces with a reversion to the atavistic stereotyping of the French as the 'other'. This combination was too strong not to impregnate the British collective memory of $1940 .{ }^{43}$ Richard Weight argues that the collapse of the Franco-British alliance in 1940 "marked the start of the patriotic legend of the Finest Hour, according to which the British - standing alone and defiant on their island home - saved the world from tyranny." ${ }^{44}$ Numerous writers and historians have recorded that some British people in 1940 were glad - elated even - that Britain was now rid of its ally and that it faced the enemy alone in the ultimate contest between heavyweights. ${ }^{45}$ But, as Michael Howard has written, "agreeable as such sentiments may have been, they were totally illusory, and they were shared neither by the Prime Minister nor by the Chiefs of Staff." 46 The Ministry of Information took a similar view. Home Intelligence commented at the time of the French request for an armistice that "Many people express relief (of a quite unrealistic kind) that at last 'There are no more Allies." ${ }^{47}$ The reality was, as David Edgerton for example has pointed out, Britain was not alone. ${ }^{48}$ It still had its dominions and 
empire as comrades-in-arms and, also, access to the potentially crucial economic assistance of the United States.

Résistante, so "Churchill convinced the British that they would never have surrendered". By definition, Churchill was making a counter-factual assertion, namely that Britain would have continued to fight, come what may. "At the root of this hubris was the fact that the British had not been invaded. Nor had their national character been questioned by subsequent defeat and collaboration." ${ }_{55}$ At the same time, the myth of invincibility downplays the crucial factor of Britain as an island fortunate in being defended by the sea. A symptom of this hubris were the numerous and hugely successful British films of the nineteen fifties and early sixties conveying a nostalgic and reassuring view of Britain's role in the Second World War, a war which Britain had ostensibly won single-handedly. ${ }^{56}$ This variation on the theme of 'Britain alone' consisted of portraying in film stiff upperlipped characters (usually male), confronting or fighting against overwhelming numbers and acquitting themselves honorably, ultimately successfully. But this interpretation of Britain alone ignores the crucial fact that the war was a world war. It ignores the wider picture. As Mark Connelly remarks (endorsing Malcolm Smith), these films are evidence that Britain quickly forgot that "the most significant fact about 1940 was the collapse of France and its political and military implications ... As a nation we have no concept of the vital importance of France in 1940 as a great bastion against fascism, as a great nation, as a great military power, as a great empire." ${ }_{57}$

\section{Conclusion}

Britain's rejection of peace with Hitler in 1940 was an important turning point in the war. In the eyes of the British, the eclipse of France and much of continental Europe made their country all the more heroic, all the more glorious in their resistance to the enemy. As Robert and Isabelle Tombs remind us, "France's defeat was seen by many in Britain ... as a failure of determination, leadership and national cohesion." Yet, Britain's "contribution to the Alliance was shamefully feeble." 58 If we accept Richard Weight's thesis 
that the British people felt guilty about appeasement - and 'Cato's Guilty Men was a symptom of that national guilt ${ }^{59}$ - the following questions arise: could it be that, buried under the resentment that Britain was abandoned by France in 1940, there lingered a guilty conscience that Britain had failed France diplomatically and militarily; that its pre-war policy of keeping France at arm's length and its refusal to enter into a formal military alliance with France until almost the last minute amounted to a colossal dereliction, a betrayal even of France? Does this guilty conscience - if it exists concede that the ten divisions of the British Expeditionary Force in 1940 were a paltry contribution to France's defence on land, a contribution that would have been laughable if its consequences had not been so disastrous? These questions are worth pondering, I suggest. Work still needs to be done to determine the exact nature of the British collective memory of the fall of France and of Britain's direct if partial responsibility for the defeat of 1940 . Is there a single memory or are there multiple memories? How much is explicit, how much sub-conscious? How did the British memory of France in 1940 evolve and how did it affect attitudes to the France from then to the present? How did myths and prejudices combine? Can further research help us to disentangle the myths and prejudices from the reality?

\section{BIBLIOGRAPHY}

Ministry of Information papers INF 1/264, National Archives, Kew, London.

Daily Express.

Daily Herald.

Daily Mail.

Daily Sketch.

Daily Worker.

News Chronicle.

The Daily Telegraph.

The Manchester Guardian.

The Spectator.

The Times.

House of Commons Debates (Hansard) June 1940.

BBC Television, Have I Got News For You? 31 October 2014.

Addison, Paul and Crang, Jeremy A. (eds.), Listening to Britain: Home Intelligence Reports on Britain's Finest Hour May to September 1940 (London, The Bodley Head, 2010).

Anonymous, Instructions for British Servicemen in France 1944 (Oxford, Bodleian Library, 2005). 
Atkin, Nicholas, The Forgotten French: Exiles in the British Isles 1940-44 (Manchester, Manchester University Press, 2003).

Avon, The Earl of, The Eden Memoirs; The Reckoning (London, Cassell, 1965).

Bell, P. M. H., A Certain Eventuality: Britain and the Fall of France (Farnborough, Saxon House, 1974).

Bell, P. M. H., France and Britain 1900-1940: Entente and Estrangement (Harlow, Longman, 1996).

Black, Jeremy, Rethinking World War Two: The Conflict and its Legacy (London, Bloomsbury, 2015).

Bond, Brian, Britain's Two World Wars against Germany: Myth, Memory and the Distortions of Hindsight

(Cambridge, Cambridge University Press, 2014).

Butler, Harold, The Lost Peace: A Personal Impression (London, Faber and Faber, 1941).

Calder, Angus, The People's War: Britain 1939-1945 (London, Pimlico, new edition 1992).

‘Cato', Guilty Men (Harmondsworth, Penguin, 1998, originally published by Victor Gollancz, 1940).

Carswell, Richard, The Fall of France in the Second World War: History and Memory (London, Palgrave Macmillan, 2019).

Chapman, James, The British at War: Cinema, State and Propaganda 1939-1940 (London, I. B. Tauris, 1998).

Connelly, Mark, We Can Take It! Britain and the Memory of the Second World War (Harlow, Pearson, 2004).

Eccles, David (ed.), By Safe Hand: The Letters of Sybil and David Eccles (London, The Bodley Head, 1983).

Edgerton, David, The Rise and Fall of the British Nation: a Twentieth-Century History (London, Penguin, 2018).

Gardiner, Juliet, Wartime Britain 1939-1945 (London, Headline, 2004).

Gilbert, Martin, Finest Hour: Winston S. Churchill 1939-1941 (London, Book Club Associates / Heinemann, 1983).

Hastings, Max, Finest Years: Churchill as Warlord 1940-45 (London, Harper Press, 2009).

Howard, Michael, The Continental Commitment: the dilemma of British defence policy in the era of two world wars (London, Ashfield Press, 1972 reprinted 1989).

Hurd, Geoff (ed.), National Fictions: World War Two in British Film and Television (London, British Film Institute, 1984).

Ismay, Lord, The Memoirs of Lord Ismay (London, Heinemann, 1960).

Lyttleton, Oliver (Viscount Chandos), The Memoirs of Lord Chandos (London, The Bodley Head, 1962).

Malcolmson, Robert (ed.), Love and War in London: The Mass Observation Wartime Diary of Olivia Cockett (Stroud, The History Press, 2009).

Mangold, Peter, Britain and the Defeated French: From Occupation to Liberation 1940-1944 (London, I. B. Tauris, 2012).

McLaine, Ian, Ministry of Morale: Home Front Morale and the Ministry of Information in World War II (London, Allen and Unwin, 1979).

Nord, Philip, France 1940: Defending the Republic (New Haven, Yale University Press, 2015). 
Rist, Charles, Season of Infamy: A Diary of War and Occupation 1939-1945 (Bloomington, Indiana University Press, 2016).

Smith, Colin, England's Last War Against France: Fighting Vichy 1940-1942 (Weidenfeld \& Nicolson, 2009).

Smith, Malcolm, Britain and 1940: History, Myth and Popular Memory (London, Routledge, 2000).

Thomas, R. T., Britain and Vichy: The Dilemma of Anglo-French Relations 1940-42 (New York, St Martin's Press, 1979).

Tombs, Robert and Isabelle, That Sweet Enemy: The French and the British from the Sun King to the Present (London, Heinemann, 2006).

Tombs, Robert and Chabal, Emile (eds.), Britain and France in Two World Wars: Truth, Myth and Memory (London, Bloomsbury, 2013).

Weight, Richard, Patriots: National Identity in Britain 1940-2000 (London, Macmillan, 2002).

\section{NOTES}

1. P. M. H. Bell, A Certain Eventuality: Britain and the Fall of France (Farnborough, Saxon House, 1974). More recent works include R. T. Thomas, Britain and Vichy: The Dilemma of Anglo-French Relations 1940-42 (New York, St Martin's Press, 1979); Robert and Isabelle Tombs, That Sweet Enemy: The French and the British from the Sun King to the Present (London, Heinemann, 2006); Colin Smith, England's Last War Against France: Fighting Vichy 1940-1942 (London, Weidenfeld \& Nicolson, 2009); Peter Mangold, Britain and the Defeated French: From Occupation to Liberation 1940-1944 (London, I. B. Tauris, 2012); Robert Tombs and Emile Chabal (eds), Britain and France in Two World Wars: Truth, Myth and Memory (London, Bloomsbury, 2013).

2. Paul Addison and Jeremy A. Crang (eds.), Listening to Britain: Home Intelligence Reports on Britain's Finest Hour May to September 1940 (London, The Bodley Head, 2010).

3. Home Intelligence Report, Friday 24 May 1940, reproduced in Addison and Crang (eds.), Listening to Britain, p. 25; (hereafter HIR).

4. The Times, 29 May 1940, p. 4; The Manchester Guardian/Daily Sketch, 29 May 1940, p. 5; News Chronicle/Daily Herald/Daily Mail, 29 May 1940, p. 8.

5. Daily Express, 30 May 1940, p. 4.

6. The Manchester Guardian, 31 May 1940, pp. 4, 5.

7. The Daily Telegraph, 4 June 1940, pp. 1, 8; Daily Sketch, 4 June 1940, pp. 1, 3; 5 June 1940, pp. 3, 5, 16; Daily Mail, 4/5 June 1940, pp. 1, 3, 4; Daily Worker, 5 June 1940, p. 4; The Spectator, 7 June 1940, p. 766.

8. Daily Express, 4 June 1940, pp. 3, 4. See also The Manchester Guardian, 4 June 1940, p. 5.

9. Daily Mail, 4 June 1940, p. 4.

10. The Manchester Guardian, 4 June 1940, p. 6. See also The Daily Telegraph, 4 June 1940, p. 5; News Chronicle, 4 June 1940, p. 8 ; 8 June 1940, p. 5; 9 June 1940, p. 1.

11. HIR, Tuesday 4 June 1940, p. 75.

12. HIR, Tuesday 4 June 1940, p. 76.

13. HIR, Wednesday 5 June 1940, p. 80.

14. HIR, Monday 10 June 1940, p. 97.

15. HIR, Saturday 15 June 1940, p. 115.

16. HIR, Monday 17 June 1940, p. 123.

17. HIR, Tuesday 18 June 1940, p. 126. On 17 June Churchill broadcast: "The news from France is very bad and I grieve for the gallant French people who have fallen into this terrible misfortune. Nothing will 
alter our feelings towards them, or our faith that the genius of France will rise again." Martin Gilbert, Finest Hour: Winston S. Churchill 1939-1941 (London, Book Club Associates / Heinemann, 1983) p. 566. 18. House of Commons Debates (Hansard), 18 June 1940, volume 362, columns 51-64.

19. HIR, Wednesday 19 June 1940, p. 129.

20. HIR, Thursday 20 June 1940, p. 133.

21. Daily Sketch, 20 June 1940 , p. 7.

22. HIR, Friday 21 June 1940, p. 141.

23. HIR, Monday 24 June 1940, pp. 149-150.

24. See, for example, The Times, 24 June 1940, p. 2; Daily Worker, 24 June 1940, p. 1.

25. HIR, Tuesday 25 June 1940, p. 156.

26. Daily Sketch, 27 June 1940, p. 7. The paper invented a new word meaning to betray: "Pétainer".

27. See, for example, Daily Express, 27 June 1940, pp. 1-2; Daily Mail, 27 June 1940, p. 1.

28. HIR, Saturday 6 July 1940, p. 196.

29. Memorandum by Minister of Information, 20 July 1940, CAB 66/10, National Archives, quoted in Ian McLaine, Ministry of Morale: Home Front Morale and the Ministry of Information in World War II (London, Allen and Unwin, 1979) p. 103; Bell, A Certain Eventuality, p. 283.

30. Addison and Crang, Listening to Britain, p. xvi.

31. P. M. H. Bell, France and Britain 1900-1940: Entente and Estrangement (Harlow, Longman, 1996), p. 252.

32. See, for example, Robert Malcolmson (ed.), Love and War in London: The Mass Observation Wartime Diary of Olivia Cockett (Stroud, The History Press, 2009), p. 100; Max Hastings, Finest Years: Churchill as Warlord 1940-45 (London, Harper Press, 2009), pp. 55-56.

33. Nicholas Atkin, The Forgotten French: Exiles in the British Isles 1940-44 (Manchester, Manchester University Press, 2003) p. 23.

34. 'Cato', Guilty Men (Harmondsworth, Penguin, 1998; originally published by Victor Gollancz, 1940), p. 122.

35. Gilbert, Finest Hour, pp. 663-665.

36. Gun Buster, Return Via Dunkirk (London, Hodder and Stoughton, 1940) pp. 148-149, 221.

37. For an overview of Went The Day Well? see James Chapman, The British at War: Cinema, State and Propaganda 1939-1945 (London, I. B. Tauris, 1998), pp. 83, 226-228.

38. David Eccles (ed.), By Safe Hand: The Letters of Sybil and David Eccles (London, The Bodley Head, 1983), 17 May 1942, p. 380.

39. Richard Weight, Patriots: National Identity in Britain 1940-2000 (London, Macmillan, 2002), p. 109. 40. Charles Rist, Season of Infamy: A Diary of War and Occupation 1939-1945 (Bloomington, Indiana University Press, 2016), Sunday 2 November 1940, p. 82; (originally published as Une Saison Gâtée; Journal de la guerre et de l'occupation 1939-1945, Paris, Fayard, 1983).

41. Harold Butler, The Lost Peace: A Personal Impression (London, Faber and Faber, 1941) pp. 87-88.

42. Anonymous, Instructions for British Servicemen in France 1944 (Oxford, Bodleian Library, 2005) no page number.

43. See, for example, Bell, France and Britain 1900-1940, pp. 250-252; Mark Connelly, We Can Take It! Britain and the Memory of the Second World War (Harlow, Pearson, 2004), p. 63; Malcolm Smith, Britain and 1940: History, Myth and Popular Memory (London, Routledge, 2000), pp. 40, 132.

44. Weight, Patriots, p. 27.

45. See, for example, The Earl of Avon, The Eden Memoirs: The Reckoning (London, Cassell, 1965) p. 113; Oliver Lyttleton (Viscount Chandos), The Memoirs of Lord Chandos (London, The Bodley Head, 1962) p. 160; Lord Ismay, The Memoirs of Lord Ismay (London, Heinemann, 1960) p. 146; Angus Calder, The People's War: Britain 1939-1945 (London, Pimlico, new edition 1992) p. 113; Juliet Gardiner, Wartime Britain 1939-1945 (London, Headline, 2004) p. 219.

46. Michael Howard, The Continental Commitment: the dilemma of British defence policy in the era of two world wars (1972, reprinted London, Ashfield Press, 1989) p. 143. 
47. HIR, Tuesday 18 June 1940, p. 126.

48. David Edgerton, The Rise and Fall of the British Nation: a Twentieth-Century History (London, Penguin, 2018) p. 64.

49. Weight, Patriots, p. 109.

50. Richard Carswell, The Fall of France in the Second World War: History and Memory (London, Palgrave Macmillan, 2019) passim.

51. Philip Nord, France 1940: Defending the Republic (New Haven, Yale University Press, 2015), p. 86,

52. Brian Bond, Britain's Two World Wars against Germany: Myth, Memory and the Distortions of Hindsight (Cambridge, Cambridge University Press, 2014) p. 2.

53. Jeremy Black, Rethinking World War Two: The Conflict and its Legacy (London, Bloomsbury, 2015) pp. 15, 106-107.

54. Have I Got News For You?, BBC2 Television, broadcast 31 October 2014, rebroadcast 13 July 2015. Remark by the presenter Damian Lewis regarding Afghanistan and writing new textbooks on how to lose wars: "It would have been cheaper just to translate the original French one."

55. Weight, Patriots, pp. 110-111.

56. Bond, Britain's Two World Wars, pp. 10-11, 16-17. Examples of such films include The Wooden Horse (1950), Angels One Five (1952), The Cruel Sea (1953), The Dam Busters (1955), Reach for the Sky (1956), Dunkirk (1958), Sea of Sand (1958).

57. Connelly, We Can Take It! p. 273, pp. 280-281; Smith, Britain and 1940, p. 8, pp.120-123. On films, see also Geoff Hurd (ed.), National Fictions: World War Two in British Films and Television (London, British Film Institute, 1984).

58. Tombs, That Sweet Enemy, p. 564.

59. Weight, Patriots, pp. 48, 114-115.

\section{ABSTRACTS}

Although British views on the fall of France in 1940 were mixed, the disaster triggered a latent Francophobia which expressed itself in popular resentment at France's military defeat and armistice with Germany. While nowadays historians generally agree on the military causes of the fall of France, British popular attitudes to France at the time of the defeat were influenced by the myths that rapidly formed around Britain's stance in 1940. By the end of the war the British had developed a sense of superiority over continental Europeans. But they also felt guilty about Britain's failed pre-war policy of appeasement. Questions for historians to ponder include how far this feeling of guilt covered - if at all - Britain's lukewarm diplomatic and military support for France.

Alors que l'opinion était partagée au Royaume-Uni quant aux causes de la défaite française, la débâcle raviva une francophobie latente qui se manifesta dans un ressentiment populaire face à la défaite militaire de la France et à l'armistice avec l'Allemagne. Si aujourd'hui la plupart des historiens s'accorde sur les causes militaires de la défaite française, l'opinion de la population à l'égard de la France fut influencée par les mythes qui se formèrent rapidement autour de la position britannique en 1940. A la fin de la guerre, les Britanniques avaient développé un sentiment de supériorité vis-à-vis de l'Europe continentale mais également un sentiment de culpabilité face à l'échec de la politique d'apaisement d'avant-guerre. Il revient aux historiens de 
déterminer si ce sentiment de culpabilité concernait un tant soit peu la timidité du soutien militaire et diplomatique que les Britanniques avaient apporté à la France.

\section{INDEX}

Mots-clés: histoire de France, Deuxième Guerre Mondiale, défaite de 1940, alliés Keywords: France's history, Second World War, defeat of 1940, allies

\section{AUTHOR}

RICHARD CARSWELL

Independent Historical Researcher

Richard Carswell is an independent researcher specializing in European history of the midtwentieth century. He was awarded his doctorate of philosophy by the University of Reading in 2008 for his thesis on France and the British press in 1939-1940. His book The Fall of France in the Second World War: History and Memory was published by Palgrave Macmillan in 2019. He is a reviewer for the journal French History (published by Oxford University Press). He is currently translating into English a work on the Italian intervention in the Spanish Civil War. 